\title{
The role of parents and teachers in developing students' problem-solving creativity through scout activity
}

\author{
Khulatul Lutfiah ${ }^{1}$, Sri Marwiyati ${ }^{2}$, Hesti Ariestina ${ }^{3}$ \\ 1,3 Madrasah Ibtidaiyah Teacher Education Study Program IAIN Salatiga \\ 2 Early Childhood Islamic Education Study Program \\ Email: khulatul@iainsalatiga.ac.id
}

\begin{abstract}
This research aims to know parents' and teachers' role in developing problemsolving creativity by Scouting Activity in MIN Salatiga and MI Ma'arif Mangunsari. Besides that, it is to see the form of program to create the problem-solving creativity in the Scouting Activity in these Islamic School.

This research is qualitative research, which results from the descriptive data. The technique of collecting the data include interview, documentation, and questionnaire. The data was analyzed using the Data Reduction Method, Data Presentation, and the Data Validity Test using triangulation.

This research shows that: 1) Both MIN Salatiga and MI Ma'arif Mangunsari give immense support in developing problem-solving creativity. 2) The development of problem-solving creativity in the Scouting Activity in MIN Salatiga and MI Ma'arif Mangunsari principled on mastering five primary Scouting skills containing Spiritual, Emotional, Social Skill, Managerial Skill, and Physical Skill. From several techniques and material given by the Scouting, guidance can make the students capable of seeking problem-solving, which can be applied to themselves and the society around them.
\end{abstract}

Keywords: Role, Problem-solving Creativity, Scouting, Primary School

\section{INTRODUCTION}

Extracurricular is an operational tool (supplements and complements) in the school curriculum, Boy Scouts. UU no. 12 of 2010 states that the Scout Movement is an organization formed by scouts to organize scouting education that prepares its members to have the Dasa Dharma and Tri Satya (Mukhlas 
$\mathrm{M}$, 2017). In gaining as much learning experience and information as possible, the Scout extracurricular application is expected to make a major contribution to increasing children's creativity, developing children's character and intelligence to solve simple problems. If this is done regularly, the children will be reliable and ready to face future times.

Every child has more than one potential intelligence that can develop. According to what Gardner said (2011), "people are born with a certain amount of intelligence," even though these developments differ from one person to another. With their potential, children always need creative activities and ideas. They need proper coaching to develop their potential and abilities optimally. To achieve success in life, not only through intelligence alone, but children need an independent mental attitude, self-confidence, and courage to face difficulties. So that in addition to children's intelligence that must be developed is children's creativity in achieving life goals.

Children's creativity will not develop properly if there is no conducive stimulus to develop it. For the formation of student creativity to be formed through scout extracurricular activities, good scout management and support from various parties are needed, not only the teacher's responsibility but also personal responsibility, parents and the community.

Parents' role is enormous in helping children be ready to enter the gates of their lives. Parents' care as the first and foremost teacher for their children must do something useful for their children. The Indonesian nation's future is in their children's hands as the nation's next-generation and their current parents are preparing for their future. As long as the community, parents, and 
school support each other, children's creativity can develop properly (Semiawan, 2009).

This research was conducted at MIN Salatiga and MI Ma'arif Mangunsari, Sidomukti District. MIN Salatiga is the only public madrasah in Salatiga and has many achievements, and extracurricular activities for its scouts are actively carried out in the madrasah. Meanwhile, MI Ma'arif Mangunsari is a private madrasah with many academic achievements and achievements in the scouting field. The madrasah was selected to represent Sidomukti Subdistrict in the 2019 Salatiga City Scout Front Cluster Administration competition.

Scout coaches have an important role in scouting activities, so a coach must improve their quality. Scouting activities' success depends on the coach because it is the spearhead in the scout learning process. Scouting coaches have the following roles as parents, teacher, brother, partner, friend, consultant, motivator, facilitator.

According to Robert Franken, quoted by Momon Sudarma, three motivations cause a person to create, namely: (1) the need to have something new, varied, and better; (2) The urge to communicate values or ideas; (3) The desire to solve problems. The three motivations that underlie a person to be creative (Sudarman, 2013). Children need basic skills that can help their survival now and in the future. These basic skills are applicable and solutions. A community called CBE Kampung Juara in Salatiga created a curriculum in which children, namely must master ten basic skills: 1) Maintaining health and safety; 2) Literacy; 3) Taking care of self; 4) Communicating; 5) Serving; 6) Producing food; 7) Independent travel; 8) Using technology; 9) Financial transactions; 10) Work (Ariestina, 2016). 
Creativity encourages students to have high curiosity to find new ideas, try new things, elaborate on several opinions, be intuitive, be more realistic, and never give up (Sari et al., 2017). Creative children can solve problems calmly, do not let negative emotions dominate themselves, make problems as challenges that must be resolved so that children can solve problems well and confidently. As for the steps in problem-solving, according to Santrock, are; 1) look for and understand problems; 2) develop a good problem-solving strategy; 3) explore solutions; 4) think and redefine problems and solutions from time to time (Santrock, 2011). To become individuals who have high creativity, they must dare to be different from others.

Ajirna et al. (2018) revealed that scout education is an extracurricular activity held in schools as a vehicle for character building, carried out in the form of activities that are attractive to children and parents because together they can make games, carry out wandering, learn about health, get fun, joy, skills, and a willingness to assist others who need assistance.

Scout extracurricular is education outside the school and outside the family environment in the form of interesting and fun activities that can shape the character, personality, noble character, and spirit of creation. Extracurricular activities can prepare the younger generation as national leaders who have excellent character, personality, noble character, and life skills (Woro \& Marzuki, 2016). So that Scouting becomes an activity that is suitable for children to develop children's problem-solving creativity.

Students can develop skills and creativity through Scouting because students are given the opportunity and choice to express their desires, attitudes, and abilities fully. Scouting is an activity that can be done in the open with a fun form of play. It must consider several factors and certain skills 
that must be mastered by scout members in its implementation. Scouting skills are a necessity for scout members as capital in everyday life in society. The skills are spiritual, emotional skills, social skills, managerial skills, and physical skills (Suhadi et al., 2015).

Sedya Santosa and Afroh Nailil Hikmah in an article entitled "Efforts to Build Student Character through Scout Extracurricular Activities at SDIT Salsabila 2 Klaseman Sinduharjo Ngaglik Sleman". The efforts to form student character at SDIT Salsabila 2 Klaseman are in the form of creative, innovative, and recreational scouting activities that contain education. Scouting is packaged in interesting and fun activities and is carried out outdoors to provide students with a recreational element after a full day through the learning process (Santosa \& Hikmah, 2015).

Yeni Wulandari and Muhammad Kristiawan wrote about "School strategies in strengthening character education for students by maximizing parents' role." Strategies are carried out in strengthening character education for students by realizing it through real day-to-day activities, building strong relationships between students, preparing educators responsible educators, and conditioning a safe, comfortable Islamic school environment both in worship, work, and social relationships social, and cleanliness (Wulandari \& Muhammad, 2017).

Ratna Sari Dewi, in her writing "Training of Enforcement Scouts in Developing the Creativity of Its Members in Pursuing Package C Harapan Bangsa Village Balonggandu, Jatisari District, Karawang Regency." The results showed that the Scout Training was quite good at developing its members' creativity; this can be seen from some of the members who began to develop their creativity in terms of their ideas, ideas, and work cubes (Dewi, 2017). 
Miwa Patnani, in his research, that efforts to improve problem-solving abilities can be grouped into three categories, namely increasing cognitive abilities, improving the quality of teaching methods, and improving the quality of teachers. Cognitive Enhancement through increasing student sensitivity, recognizing problems, critical thinking, and creativity. Improved teaching methods will hone problem-solving skills. To improve teachers' quality, teachers need to make themselves a good example in solving problems (Patnani, 2013).

After reviewing some of these studies' results, the authors argue that this study is different from previous studies. Although more or less discussed parents' role, Scout extracurricular activities, and creativity development, it has not fully focused on parents and teachers' role in developing student problemsolving creativity through scout extracurricular activities. This research focuses on the extent to which parents and teachers' role in developing students' creative problem-solving through scout extracurricular activities held at Madrasah Ibtidaiyah.

Based on the background of the problem and review of theory and literature, the authors research about How the role of parents and teachers in developing problem-solving creativity through Scouting extracurricular activities at MIN Salatiga and MI Ma'arif Mangunsari, as well as how to develop problem-solving creativity in Scout Extracurricular activities at MIN Salatiga and MI Ma'arif Mangunsari.

\section{METHODS}

This research is descriptive qualitative research. For the data sources of this research, namely the principal as manager and policymaker, teachers, in 
this case, are scout coaches, students involved in scouting activities, and student guardians who know the child's development. At the same time, at home and the roles have been given both at home and at school.

Observations were made by directly observing the Scout extracurricular activities at MIN Salatiga and MI Ma'arif Mangunsari. Seeing the planning made by Scout coaches, the implementation of scout extracurricular activities and the development of creativity that occurs and the manifestation of children's creativity. Observation of the object of events in the field aims to get to know more closely the role of scout coaches in developing children's problem-solving creativity and emerging children's problem-solving creativity.

This study using structured and unstructured interviews. These interviews were addressed to school principals, scout coaches, and parents in both madrasahs. So, from the interview, it can be seen that parents' and teachers' role in developing creative problem-solving through scouts.

In this case, the researchers extracted data from scout coaches' documents about scouting activities, children's creativity, and parents' role in developing children's creativity. Documentation is also carried out when scouting extracurricular activities by taking pictures and noting things related to the learning process so that it becomes reinforcement from interviews and observations.

In this study, the authors used a closed questionnaire. It provides questions and answers so that the respondents only gave limited answers. The targets given a questionnaire are parents and students in grades 4, 5, and 6 of MIN Salatiga and MI Ma'arif Mangunsari. This research was conducted from March to August 2020 at MIN Salatiga and MI Ma'arif Mangunsari Salatiga. The research data that has been obtained from MIN Salatiga and MI Ma'arif 
Mangunsari are then analyzed. The data analysis process involves sorting the data, arranging the data into patterns, categories, and basic descriptive units. The next step is to report the full research results, with new, different findings.

\section{DISCUSSION}

\section{MIN Salatiga}

Madrasah Ibtidaiyah Negeri Salatiga is a madrasah located in Salatiga and the only Madrasah Ibtidaiyah with public status in Salatiga. MIN Salatiga has a Front Cluster number 02.279 - 02.280, which is led by Mr. Samhudi, S.Pd, who acts as the Chairperson of the Front Cluster Advisory Council (Kamabigus) who is the protector, person in charge, and the party approving the program design.

MIN Salatiga has a scouting work program and a training program. Planning for Scout extracurricular activities at MIN Salatiga in one year, namely: a) Compilation of materials according to the SKU book; b) Routine training schedule once a week, namely every Friday at 13.00-15.00; c) Scout activities such as Saturday and Sunday camps for mobilizers; d) SKU testing schedule, e) Facilities and Infrastructure; f) Fund for activities.

Besides, MIN Salatiga also plans a weekly activity program. This weekly activity program is made to carry out every routine scout training agenda. Scout training activities at MIN Salatiga are routinely held every Friday. Students from grade 3 attended this scout training to grade 6 . Grades 3 and 4 were members of the standby scouts, grades 5 and 6 were members of the mobilizer. This activity is held every Friday, from 13.00 to 15.00 . 
To support scouting in students, support and roles are needed from various parties, both from home and school. One of the roles of madrasas in developing scout quality at MIN Salatiga is developing their coaches' skills and abilities. MIN Salatiga engages teachers in the development skills of coaches such as Basic Course of Scout Coach (KMD) of Branch Office (Kwarcab) organized by the Salatiga City government and Basic Course of Scout Coach (KMD) of Regional Counter (Kwarda) organized by the province of Central Java. The goal is that the coach has basic knowledge and practical experience of fostering Scouts to carry out scouting activities that are interesting, fun, challenging, and contain educational elements.

Meanwhile, the coaches' role at MIN Salatiga, apart from being scout trainers, also acts as parents in school by accompanying, providing motivation, facilitating children in routine scouting training activities, incidental activities, and competitions.

According to the explanation from the scout coaches, scout members from MIN Salatiga are always stimulated by providing training which includes material on general knowledge, religion, scouting techniques, living pharmacies, and skills for daily living needs, such as cooking, sports, P3K, saving money through compulsory weekly fees, reading maps and directions, and so on.

Mustafifah, as the Scout Guide, said that every success in scouting activities could not be separated from the support of the students' parents. For example, in the PERSARI (One Day Camp) activity, parents are very enthusiastic about completing their children's needs to know that they pay dues more quickly. And accompany their sons and daughters in the field at night. There are about $90 \%$ of parents accompanying children until the fire is 
over. Some parents volunteered to help hold the event even though they were not part of the committee. Most parents were enthusiastic about supporting every scouting activity, both routine, competitions, and outbound activities, such as outbound and camping, from the parents' interviews.

This is supported by obtaining data through a parent questionnaire. In terms of supporting children in scouting activities, $87.7 \%$ of parents support; 97.4\% of parents always motivate their children to participate in scouting activities; $74.4 \%$ of parents help prepare the equipment needed by each child scout training. Whereas in incidental activities, $53.8 \%$ of parents prepare facilities needed by children; $66.7 \%$ of parents provide logistical support and accommodation.

To develop problem-solving creativity in children, MIN Salatiga supervisors provide various scouting materials that can foster children's creative attitudes, such as games, outbound, live pharmacies, first aid kits, and other scouting materials. The students of MIN Salatiga have mastered some of the materials mentioned above.

\section{Maarif Mangunsari}

MI Ma'arif Mangunsari has the Front Cluster numbers 02.121 . 02.122. This school has a total of 581 students. MI Ma'arif Mangunsari has administrative requirements for Front Cluster. It is proven by the acquisition of 1st place in the Front Cluster administration competition at the Sidomukti District level. And become a District Sidomukti for the Front Cluster administration competition to the Salatiga City level. At that time, MI Mangunsari won fourth place at the Salatiga City level. 
In carrying out scouting activities, MI Ma'arif Mangunsari has a scout activity planning which involves the principal, teachers, in this case, scout coaches, and parents. The School's Principal acts as the Chairperson of the Front Cluster Advisory Council (Kamabigus), who is the protector, person in charge, and the party is approving the program design.

Teacher acting as a role builder for the front group as coordinator of Kamabigus, designs scout activity programs, and fosters students. The chairman of Front Cluster consists of the chairman of Boys Scout and the chairman of Girl Scout. The head of Front Cluster is also the coordinator of the male standby coaches, the women's standby coaches, the male-mobilizing coaches, and the female-raising coaches.

The scout activity program in grades 1 to 3 at MI Mangunsari for the 2013 curriculum is integrated into learning. It is held separate times for grades 4, 5, and 6, namely Fridays or Saturdays. The scout activity program at MI Ma'arif Mangunsari includes a weekly training program with scouting material, SKU evaluation, camping, nature hikes, community service, outbound, and competitions.

The supervisor often conveys the material that the supervisor refers to the manual to complete the General Skills Requirements on Alert and Raiser, published by the National Quartermaster. The book contains material on matters relating to spiritual, emotional, social, intellectual, and physical. In developing children's problem-solving creativity, in addition to using games, MI Mangunsari also applies the following materials: 1) Rigging; 2) First aid skills; 3) Sandi and Morse; 4) Line up; 5) The ability of the senses to train the understanding of the human senses, including sight, memory, hearing, smell, feeling/touch; 6) The dexterity game for the scout members the alert level is 
different from the raised level. For example, you are playing a true or false pattern, moving the ball from one point to another without touching the ball. These skills are for practicing discipline, cohesiveness, harmony, and the art of marching.

Like MIN Salatiga, the parents of students at MI Ma'arif Mangunsari also have high enthusiasm in supporting their sons and daughters to participate in routine training and incidental agendas. This can be seen in the data from the questionnaire on the role of parents. There are $85.7 \%$ of parents who always support their children to participate in scouting activities. $71.4 \%$ of parents always motivate their children to participate in scouting activities. There are $64.3 \%$ of parents always prepare the equipment needed by each child in scouting training. $43 \%$ of parents always prepare facilities for incidental activities, and $53.6 \%$ of parents always provide logistical support and accommodation in incidental scouting activities.

The study results were arranged based on the exposure to data obtained through interviews, documentation, and observation. The data collected is data that has an interpretation with a research focus and a discussion about The Role of Parents and Teachers in the Creativity Development of Problemsolving Students through Extracurricular Activities at MIN Salatiga and MI Ma'arif Mangunsari Salatiga.

1. The Role of Parents and Teachers in the Development of Student Problem-solving Creativity Through the Scout Extracurricular at MIN Salatiga and MI Ma'arif Mangunsari

The scout training program's success cannot be separated from the support of several parties, such as the madrasah itself, coaches, parents, and the community. The attention of madrasas to running scout training 
activities is also the main thing that can impact whether scouting activities are smooth, such as infrastructure, budget, and cooperation with the surrounding environment. The infrastructure owned by the two madrasas for Scouting activities is sufficient and can be utilized properly in Scout extracurricular activities. The school also includes supervisors in scouting development activities such as KMD at both Kwarcab and Kwarda levels.

As for The support and role of the parents of students, both MIN Salatiga and MI Ma'arif Mangunsari, both have high enthusiasm in supporting their children to take part in scouting extracurricular activities. They are willing to provide all the necessities and infrastructure for smooth scouting activities for their children. For matters relating to the development of problem-solving creativity, parents have a significant share. The role of parents is to complement what is stimulated by the teacher or scout coach at school. Table 1 illustrates the parents' high enthusiasm from both madrasas in supporting their daughters to participate in scouting activities.

Table 1. Data on the role of parents in the development of problemsolving creativity

\begin{tabular}{clcc}
\hline No. & \multicolumn{1}{c}{ Indicator } & \multicolumn{2}{c}{ Percentage of support } \\
\cline { 3 - 4 } & & MIN Salatiga & $\begin{array}{c}\text { MI Ma'arif } \\
\text { Mangunsari }\end{array}$ \\
\hline $\mathbf{1}$ & $\begin{array}{l}\text { Supporting children in participating in scout } \\
\text { activities }\end{array}$ & $90.0 \%$ & $85.7 \%$ \\
\hline $\mathbf{2}$ & $\begin{array}{l}\text { Motivate children in participating in scout } \\
\text { activities }\end{array}$ & $97.5 \%$ & $71.4 \%$ \\
\hline 3 & $\begin{array}{l}\text { Help prepare the equipment needed for each } \\
\text { scout training }\end{array}$ & $75.0 \%$ & $42.9 \%$ \\
\hline $\mathbf{4}$ & $\begin{array}{l}\text { Prepare facilities when schools hold incidental } \\
\text { scouting activities }\end{array}$ & $55.0 \%$ & $53.6 \%$ \\
\hline $\mathbf{5}$ & Providing logistical support and & $67.5 \%$ & \\
\hline
\end{tabular}




\begin{tabular}{llll}
\hline \multicolumn{3}{l}{$\begin{array}{l}\text { accommodation in incidental scouting } \\
\text { activities }\end{array}$} & \\
\hline 6 & $\begin{array}{l}\text { Teaching children to maintain health and } \\
\text { safety }\end{array}$ & $71.8 \%$ & $75.0 \%$ \\
\hline 7 & stimulate children's literacy & $43.6 \%$ & $53.6 \%$ \\
\hline 8 & teaches children to take care of themselves & $64.1 \%$ & $78.6 \%$ \\
\hline 9 & Teaching children to communicate & $53.8 \%$ & $75.0 \%$ \\
\hline 10 & $\begin{array}{l}\text { Teaching children to be able to serve their } \\
\text { parents and the environment }\end{array}$ & $53.8 \%$ & $60.7 \%$ \\
\hline 11 & Teaching children to produce food & $25.6 \%$ & $32.1 \%$ \\
\hline 12 & Teaching children on an independent journey & $17.9 \%$ & $46.4 \%$ \\
\hline 13 & Teaching children in the use of technology & $51.3 \%$ & $57.1 \%$ \\
\hline 14 & Teach children in financial transactions & $21.1 \%$ & $50.0 \%$ \\
\hline 15 & Teaching children to work, produce works & $20.5 \%$ & $28.6 \%$ \\
\hline & Average & $53.9 \%$ & $58.3 \%$ \\
\hline
\end{tabular}

From the results of the questionnaire above, it can be seen that the role of parents at MIN Salatiga and MI Ma'arif Mangunsari both provided great support. It can be seen that the average parent who always provides support for the development of children's problem-solving creativity through scouts is around 50\%. MIN 53.9\% and MI Ma'arif Mangunsari 58.3\%.

Parental support for children to participate in scouting activities at MIN Salatiga is very high. Still, support in providing stimulation for the development of problem-solving creativity, which includes ten basic abilities that must be possessed by children, is not all optimal, such as teaching children to travel independently only revolves around $17.9 \%$ of parents who always provide support, in teaching children to financial transactions only $21.1 \%$ of parents always teach, and in teaching children to work and produce work, only $20.5 \%$ of parents always teach.

MI Ma'arif Mangunsari also has the same. The development of problem-solving creativity includes ten basic abilities that children must 
master; not all of them get maximum support from parents, namely teaching children to work; only $28.6 \%$ of parents always teach.

Table 2 is a table of children's creative problem-solving abilities, which includes ten basic life skills through questionnaires sent to students in grades 4, 5, and 6 of MIN Salatiga and MI Ma'arif Mangunsari.

Table 2. Data on children's creative problem-solving abilities

\begin{tabular}{llcc}
\hline \multirow{2}{*}{ No. } & \multicolumn{1}{c}{ Question indicator } & \multicolumn{2}{c}{ Child Ability Percentage } \\
\cline { 3 - 4 } & & MIN Salatiga & $\begin{array}{c}\text { MI Ma'arif } \\
\text { Mangunsari }\end{array}$ \\
\hline $\mathbf{1}$ & Able to maintain health and safety & $50 \%$ & $72.7 \%$ \\
\hline $\mathbf{2}$ & Literacy skills & $60 \%$ & $77.3 \%$ \\
\hline $\mathbf{3}$ & Able to take care of yourself & $50 \%$ & $50 \%$ \\
\hline $\mathbf{4}$ & Able to communicate & $77 \%$ & $81.8 \%$ \\
\hline $\mathbf{5}$ & Able to serve parents and the environment & $57 \%$ & 68.25 \\
\hline $\mathbf{6}$ & Able to process food & $13 \%$ & $54.5 \%$ \\
\hline $\mathbf{7}$ & Able to travel independently & $43 \%$ & $59.1 \%$ \\
\hline $\mathbf{8}$ & Able to use technology & $54 \%$ & $86.4 \%$ \\
\hline $\mathbf{9}$ & Able to manage finances & $14 \%$ & $36.4 \%$ \\
\hline $\mathbf{1 0}$ & Able to work, produce works $\quad$ Average & $20 \%$ & $45.5 \%$ \\
\hline & $\quad 44 \%$ & $63 \%$ \\
\hline & $\quad$ & & \\
\hline
\end{tabular}

Table 2 shows that the percentage of problem-solving creativity skills mastered by students at MIN Salatiga is still below 50\%, while at MI Ma'arif Mangunsari, above 50\% of children have mastered basic life skills. MI Ma'arif Mangunsari is higher because the support from parents is also higher.

Support from parents at MI Ma'arif Mangunsari 58.3\% and mastery of creative problem-solving for children 63\%. In MIN Salatiga, the percentage of parental support is $53.9 \%$, and the percentage of children's problem- 
solving creativity is $44 \%$. This may imply that high support also has a high effect on children's creative problem-solving abilities.

In managing the scouting activities, the two madrasahs have carried out activities well in a fun way with various games, presenting them in an interesting and challenging manner and providing a means for activities. This is in line with what Joko Mursitho (2010) expressed in managing a good scout unit: presenting interesting, fun, and challenging activities such as; camping, first aid kit, roaming, community service, bonfires.

The differences in scouting activities between the two madrasas are as follows:

a. Since first grade, scout members at MI Ma'arif Mangunsari have received scout training integrated into co-curricular activities or school learning. Meanwhile, MIN Salatiga, scout members receive scout training from grade three to grade 6 in semester one.

b. Evaluating the achievement of children's abilities in the scouting field at MIN Salatiga uses General Skills Requirements (SKU) and Special Skills Requirements (SKK). Meanwhile, in MI Ma'arif Mangunsari, apart from using the General Skills Requirements (SKU) and Special Skills Requirements (SKK), there is also a personal logbook of scout members who assess their attitudes, personalities, and history of activities they have participated in.

2. The developing creativity in problem-solving activities Extracurricular Scouts at MIN Salatiga and MI Ma'arif Mangunsari

Scouting is an extracurricular activity that is shown to train and educate students as a form of training that is oriented towards survival 
(survival of life), the formation of a noble personality, a social spirit, and human solidarity; both in terms of individual skills and collective skills which are manifested in disciplinary activities towards common rules. The practice of this activity is carried out through an organizational forum called scouts. Through this activity, students are trained to explore, hone skills in solving life's problems, conquer natural obstacles and challenges, care for social and environmental issues, organize teams, and take action (RI, 2005).

According to Suhadi ( 2015), The main skills of Scouting consist of spiritual skills, emotional skills, social skills, managerial skills, and physical skills. To develop these skills MIN Salatiga and MI Ma'arif Mangunsari develop creative problem-solving in children, described in Table 3.

Table 3. Development of Creativity Problem-solving for children

\begin{tabular}{|c|c|c|}
\hline Ultimate skill & Forms of activity & $\begin{array}{c}\text { Children's problem-solving skills } \\
\text { and creativity }\end{array}$ \\
\hline $\begin{array}{l}\text { Spiritual } \\
\text { Skills }\end{array}$ & $\begin{array}{l}\text { 1. Practicing religious principles } \\
\text { 2. Practicing the basic principles of } \\
\text { Scouting } \\
\text { 3. Scouting code of ethics practice } \\
\text { 4. Pancasila practice }\end{array}$ & $\begin{array}{l}\text { Children can take care of } \\
\text { themselves, manage their time, } \\
\text { plan plans, know good and bad } \\
\text { things and make decisions }\end{array}$ \\
\hline $\begin{array}{l}\text { Emotional } \\
\text { skills }\end{array}$ & $\begin{array}{l}\text { 1. discussion } \\
\text { 2. Give a smile, say hello, greetings } \\
\text { 3. Game } \\
\text { 4. outbound } \\
\text { 5. Looking for traces } \\
\text { 6. Campground } \\
\text { 7. race }\end{array}$ & $\begin{array}{l}\text { 1. Children can communicate: } \\
\text { give and receive input, respect } \\
\text { others and cooperate } \\
\text { 2. Children can take care of } \\
\text { themselves: manage their time, } \\
\text { stick to plans, make decisions } \\
\text { 3. Children can work: producing } \\
\text { works, taking pictures, writing } \\
\text { songs, music, stories, and so on } \\
\text { 4. Children can prepare their } \\
\text { food: processing food and } \\
\text { cooking }\end{array}$ \\
\hline Social skills & $\begin{array}{l}\text { 1. First aid training } \\
\text { 2. Live pharmacy training } \\
\text { 3. Campground }\end{array}$ & $\begin{array}{l}\text { 1. Children can maintain health, } \\
\text { safety and can perform first aid } \\
\text { 2. Children can serve others: }\end{array}$ \\
\hline
\end{tabular}




\begin{tabular}{|c|c|c|}
\hline & 4. Community service & helping parents and society \\
\hline $\begin{array}{l}\text { Managerial } \\
\text { skills }\end{array}$ & $\begin{array}{l}\text { 1. Election of the team leader to } \\
\text { raise } \\
\text { 2. Barung selection for standby } \\
\text { 3. Work in a group } \\
\text { 4. Campground } \\
\text { 5. Fill in the group presence } \\
\text { 6. Scout training opening and } \\
\text { closing ceremonies } \\
\text { 7. Member fees }\end{array}$ & $\begin{array}{l}\text { 1. Children can take care of } \\
\text { themselves: manage their time, } \\
\text { stick to plans, make decisions } \\
\text { 2. Children can prepare their } \\
\text { food: processing food and } \\
\text { cooking } \\
\text { 3. Children can manage finances: } \\
\text { shopping, saving at home, } \\
\text { school, and in the bank } \\
\text { 4. Children can use technology: } \\
\text { recognize the limits of } \\
\text { cellphone use, avoid cellphone } \\
\text { addiction, and use cellphones } \\
\text { productively }\end{array}$ \\
\hline $\begin{array}{l}\text { Physical } \\
\text { skills }\end{array}$ & $\begin{array}{l}\text { 1. Line of march } \\
\text { 2. Rigging } \\
\text { 3. Make a map } \\
\text { 4. Using compass } \\
\text { 5. Appraise } \\
\text { 6. Outbound } \\
\text { 7. Cross Country } \\
\text { 8. Semaphore } \\
\text { 9. Morse }\end{array}$ & $\begin{array}{l}\text { 1. Children can maintain health, } \\
\text { safety and can perform first aid } \\
\text { 2. Children can travel } \\
\text { independently: can read maps, } \\
\text { can go and return to their } \\
\text { place of origin } \\
\text { 3. Children are capable of } \\
\text { literacy: reading and } \\
\text { understanding what is read, } \\
\text { reading and understanding } \\
\text { instructions }\end{array}$ \\
\hline
\end{tabular}

\section{CONCLUSION}

Based on the research results, data processing, and analysis that the researcher has done, the researcher concludes several things related to the problem formulation in this study. MIN Salatiga and MI Ma'arif Mangunsari both provide good support in developing creative problem-solving among students. High parental support and interesting and fun stimulation during the coach's training affect the child's ability to master problem-solving creativity. Apart from the role of coaches and parents, there is also a role for madrasah in developing the quality of human resources for coaches and 
providing scout training facilities and infrastructure, which indirectly affects children's abilities.

The development of problem-solving creativity in Scout Extracurricular activities at MIN Salatiga and MI Ma'arif Mangunsari has the mastery of five main scouting skills: spiritual skills, emotional skills, and social skills, managerial skills, and physical skills. The five main skills, both MIN Salatiga and MI Ma'arif Mangunsari, are implemented weekly, monthly, and incidental training programs. The training program is manifested in various activities and materials, including camps, deliberations, games, out bonds, tracing, competitions, first aid training, life pharmacy training, community service, and scouting technique materials.

This study's findings are almost in line with Miwa Patnani's research, which explains that to hone creative ability, problem-solving can be grouped into three categories: increasing cognitive abilities and improving the quality of teaching methods teachers. It's just that the research conducted by the author uses five principles. Namely, mastery of five main scouting skills consisting of spiritual skills, emotional skills, social skills, managerial skills, and physical skills.

\section{REFERENCES}

Ajirna, Nasir Yusuf, and Hasmiana Hasan. 2018. "Efforts to Formation of Student Character Through School Activities in Sd Negeri 20 Banda Aceh." Primary School Teacher Education Scientific Journal 3 (3).

Ariani, Dewi. 2015. "Scout Extracurricular Management," Journal of Education Managers, 9. 
Ariestina, Hesti. 2016. "Community Based Education And Fitrah." IAIN Salatiga.

Aziz, Rahmat. 2010. Educational Psychology. Malang: UIN Maliki Press.

Danim, Sudarwan. 2000. Become a Qualitative Researcher. Bandung: Pustaka Setia, 2000).

Dewi, Ratna Sari. 2017. "Training of Enforcement Scouts in Developing the Creativity of Its Members in Pursuing Package C Harapan Bangsa Balonggandu Village, Jatisari District, Karawang Regency." Journal of Education Unsika University of Singaperbangsa Karawang 5 (1).

Emzir. 2014. Quantitative \& Qualitative Educational Research Methodology. Jakarta: Raja Grafindo.

Gardner, Howard. 2011. "Changing Minds: How the Application of the Multiple Intelligences (MI) Framework Could Positively Contribute to the Theory and Practice of International Negotiation." in Psychological and Political Strategies for Peace Negotiation: A Cognitive Approach.

Miles, Matthew B., and Michael A. Huberman. 2012. Qualitative Data Analysis: A Resource Book About New Methods. Jakarta: University of Indonesia_UI Press.

Moleong, Lexy J. 2011. Qualitative Research Methodology. Bandung: Rosdakarya.

Mukhlas M, Dedi. 2017. "Management of Scouting Extracurricular Activities at SMP Negeri 1 Yogyakarta." Hanata Widya's Journal Volume 6 (3).

Mulyasa, E. 2014. Development and Implementation of 2013 Curriculum. 
Bandung: Youth Rosdakarya.

Mursitho, Joko. 2010. Basic Advanced Course for Scout Guards. Kulonprogo: Kwarcab Kulon Progo.

Patnani, Miwa. 2013. "Efforts to Improve Problem-solving Ability in Students." Journal of Psychogenesis 1 (2).

RI, Ministry of Religion. 2005. Guide to Extracurricular Activities for Religious Education. Jakarta: Ministry of Religion of the Republic of Indonesia.

Santosa, Sedya, and Afroh Nailil Hikmah. 2015. "Efforts to Build Student Character Through Scout Extracurricular Activities at SDIT Salsabila 2 Klaseman Sinduharjo Ngaglik Sleman." Al Bidayah: Journal of Islamic Basic Education 7 (1).

Santrock, Jhon W. 2011. Educational Psychology. New York: McGraw Hill Companies.

Sari, Indah Purnama, Adri Nofrianto, and Mira Amelia Amri. 2017. "Creative Problem-solving: How It Affects Student Creativity." Journal of Elements $3(1)$.

Semiawan, Conny R. 2009. Creativity, Talent Why, What, How ,. Jakarta: Index.

Sudarman, Momon. 2013. Developing Creative Thinking Skills ,. Jakarta: Raja Grafindo.

Suhadi, Martitah, Tijan, and Mulyono. 2015. Scouting Skills (Scouting Skill). Semarang. 
Mudarrisa: Jurnal Kajian Pendidikan Islam, Vol. 12, No. 2, 2020

Suryosubroto. 2009. Learning Process in Schools. Jakarta: Rineka Cipta.

Woro, Sri, and Marzuki. 2016. "The Role of Scout Extracurricular Activities in Forming Character Responsibilities of Students at SMP Negeri 2 Windusari Magelang." Journal of Character Education 6 (1).

Wulandari, Yeni, and Kristiawan Muhammad. 2017. "School Strategies in Strengthening Character Education for Students by Maximizing the Role of Parents." Journal of Management, Leadership, and Educational Supervision 2 (2). 